\title{
Offshore seismicity in the western Marmara Sea, Turkey, revealed by ocean bottom observation
}

\author{
Yojiro Yamamoto ${ }^{1 *}$, Narumi Takahashi ${ }^{1}$, Seckin Citak ${ }^{1}$, Doğan Kalafat ${ }^{2}$, Ali Pinar $^{2}$, Cemil Gurbuz ${ }^{2}$ \\ and Yoshiyuki Kaneda ${ }^{1,3}$
}

\begin{abstract}
The faults' geometry and their seismic activity beneath the Marmara Sea have been under debate for a couple of decades. We used data recorded by three ocean bottom seismographs (OBSs) over a period of 3 months in 2014 to investigate the relationship of fault geometry to microseismicity under the western Marmara Sea in Turkey. We detected a seismic swarm at 13 to $20 \mathrm{~km}$ depth beneath the main Marmara fault (MMF), and the maximum depth of seismogenic zone was $25 \mathrm{~km}$ within the OBS observation area. These results provided evidence that the dip of the MMF is almost vertical and that the seismogenic zone in this region extends into the lower crust. Our analysis of past seismicity indicated that the seismic swarm we recorded is the most recent of an episodic series of seismic activity with an average recurrence interval of 2-3 years. The repetitive seismicity indicates that the MMF beneath the western Marmara Sea is coupled and that some of the accumulated strain is released every 2 to 3 years. Our study shows that OBS data can provide useful information about seismicity along the MMF, but more extensive studies using more OBSs deployed over a wider area are needed to fully understand the fault geometry and stick-slip behavior of faults under the Marmara Sea.
\end{abstract}

Keywords: North Anatolian fault; Marmara Sea; Ocean bottom seismograph; Seismic activity

\section{Background}

The North Anatolian fault (NAF) extends $1600 \mathrm{~km}$ from its junction with the East Anatolian fault at the Karliova triple junction in eastern Turkey. From the triple junction, it extends westward across northern Turkey and into the Aegean Sea, accommodating about $25 \mathrm{~mm} /$ year of right-lateral motion between the Anatolia and Eurasia plates (e.g., Reilinger et al. 2006) (Fig. 1). Since 1939, a sequence of devastating earthquakes of surface-wave magnitude greater than seven $\left(M_{s}>7\right)$ have ruptured progressively westward along the NAF, starting with the 1939 Erzincan earthquake $\left(M_{s}=7.9\right)$ in eastern Turkey and culminating in the 1999 Izmit-Golcuk $\left(M_{s}=7.7\right)$ and Duzce $\left(M_{s}=7.4\right)$ earthquakes in the eastern Marmara region. After the Northern Aegean earthquake $\left(M_{w}=6.9\right)$ on 24 May 2014, the only part of the 1600-km-long NAF that has not ruptured since 1939 lies beneath the Marmara Sea, where its geometry is not well understood.

\footnotetext{
* Correspondence: yamamotoy@jamstec.go.jp

'Japan Agency for Marine-Earth Science and Technology, Yokohama, Japan Full list of author information is available at the end of the article
}

Past estimates of the geometry of the NAF beneath the Marmara Sea have been based mainly on bathymetric and shallow structural information. Pinar (1943) is the first study that proposed a single through going strikeslip fault system (the main Marmara fault; MMF) that nearly bisects the Marmara Sea. Le Pichon et al. (2001) proposed a more detailed location of MMF based mainly on high-resolution bathymetry and shallow seismic reflection data. However, Armijo et al. $(2002,2005)$ identified earthquake scarps on the seafloor that suggest the presence of individual fault segments oblique to the east-west trend of the NAF, some of which they interpreted as normal faults related to opening of the Marmara Sea. To investigate the potential for future earthquakes beneath the Marmara Sea, it is necessary to clarify the fault geometry there and to know which faults are active.

Investigation of microearthquake activity might provide useful information about fault geometry and the stick-slip behavior of individual faults. However, onshore seismic stations provide insufficient data to clarify the fault geometry beneath the Marmara Sea. To obtain 


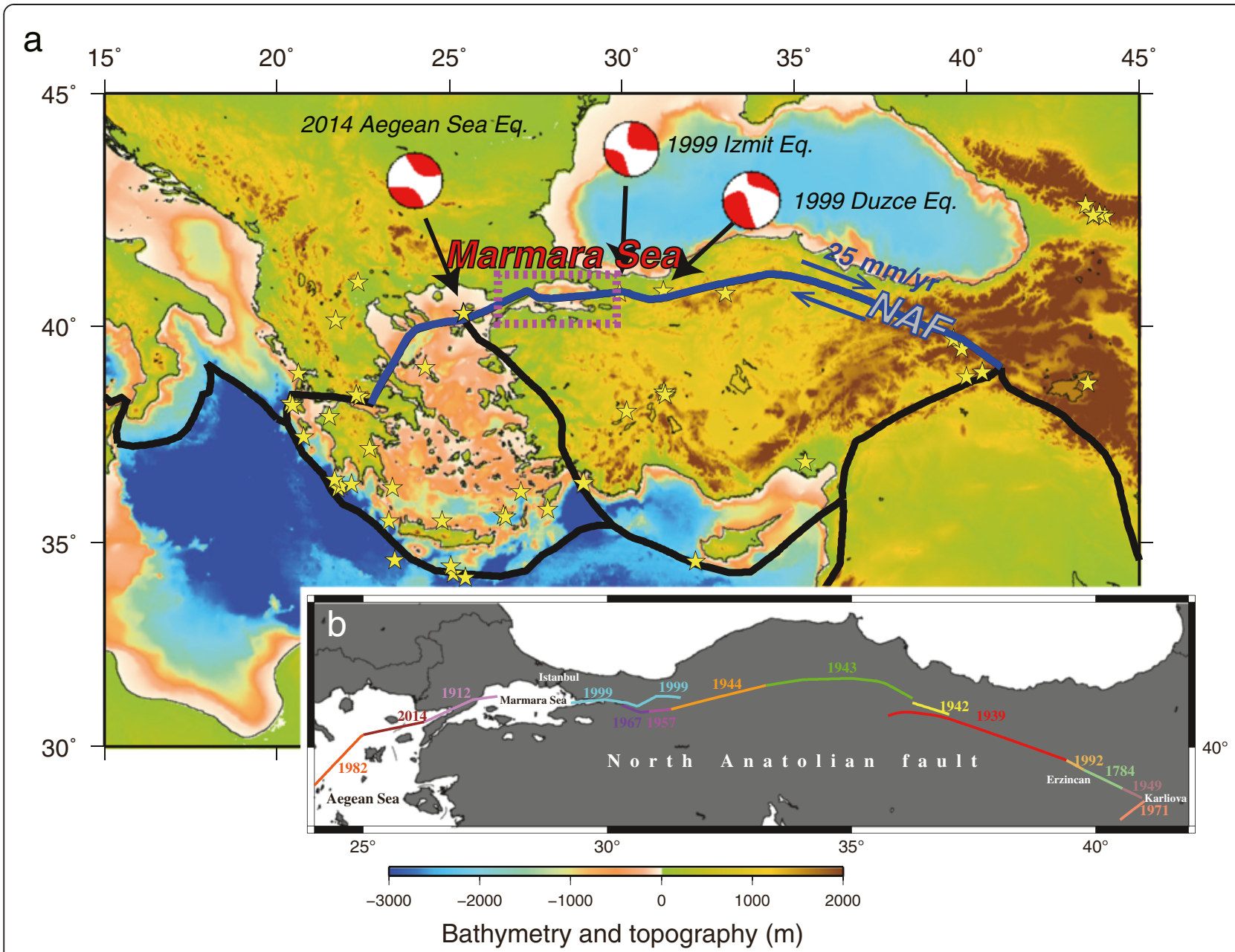

Fig. 1 Regional tectonic setting of the Marmara Sea. a Blue line is the North Anatolian fault (NAF) and black lines are other plate boundaries (Bird 2003) The slip rate of the NAF is that of Reilinger et al. (2006). The three focal mechanisms shown are from the global CMT catalogue (Dziewonski et al., 1981; Ekström et al., 2012). Epicenters of earthquakes occurred between 1990 and $2014\left(M_{w}>6\right)$ from the United States Geological Survey catalogue are shown by yellow stars. $\mathbf{b}$ Location and year of occurrence of past large earthquakes along the NAF

more-detailed information about fault geometry and seismic activity beneath the western Marmara Sea, in March 2014, we deployed three ocean bottom seismograph (OBS) stations as part of the "Marmara Disaster Mitigation" (MarDIM) project. Here, we present the results of our first observations and discuss the fault geometry beneath the western Marmara Sea and the spatiotemporal distribution of the seismicity we detected.

\section{Methods}

We deployed three free-fall pop-up OBSs in the Western High region of the Marmara Sea on March 20, 2014 and recovered them on June 18, 2014 (Fig. 2). The OBSs were equipped with three-component $4.5 \mathrm{~Hz}$ geophones and hydrophones (Takahashi et al. 2015) and were placed about $10 \mathrm{~km}$ apart on the seafloor to allow determination of the focal depths of shallow microearthquakes along the NAF. The locations of the OBSs were determined by triangulation. Clock accuracy of better than $0.05 \mathrm{~s}$ was determined by calibration of the OBS clock with GPS time just before deployment and immediately after recovery. The sampling interval was $100 \mathrm{~Hz}$. Although one OBS (site 1) operated for only the first 6 days of observations, the other two (sites 6 and 7) functioned properly throughout the 3 -month observation period.

We first identified microearthquakes that had not been recorded by the land seismic network and determined their hypocenters from the first 6 days of data when all three OBSs were operational. Although only 1 earthquake is listed for that period in the Kandilli Observatory and Earthquake Research Institute (KOERI) earthquake catalogue within the OBS network, we identified 41 events for which at least 5 (of the possible 6) P-and S-wave first arrivals were observed; the hypocenters of two-thirds of these were within the OBS network. 


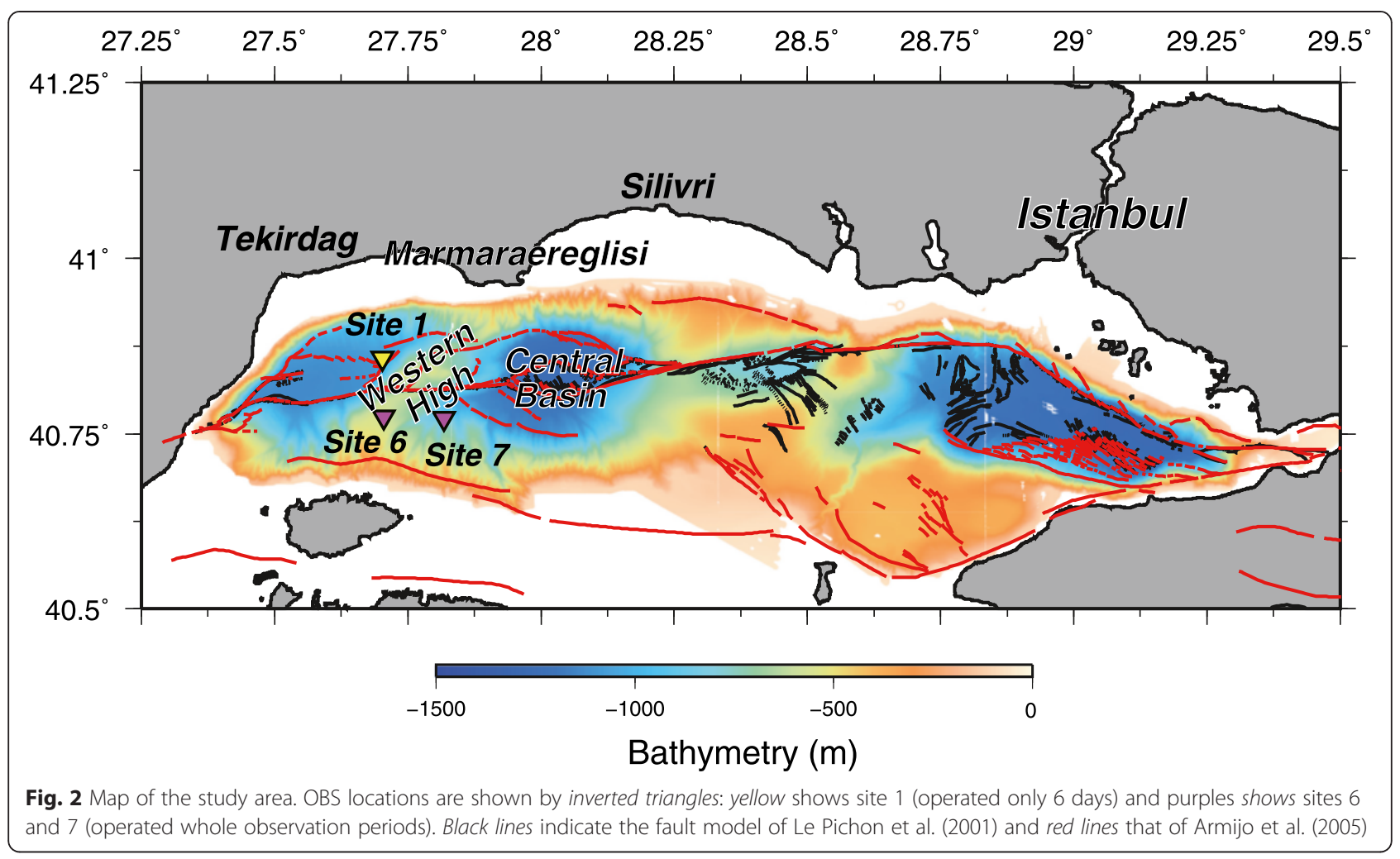

We calculated hypocenters by using the HYPOMH program (Hirata and Matsu'ura 1987). In this region, Gurbuz et al. (2000) previously developed a minimum 1$\mathrm{D}$ velocity model for land seismic stations by using the VELEST program (Kissling et al. 1994), and Bayrakci et al. (2013) developed a detailed shallow offshore Pwave structure based on data from an active-source seismic survey. We established our 1-D P-wave velocity model by combining these two previous velocity models (Fig. 3). At each station, we corrected for the travel time delays of S-wave arrivals due to the low-velocity shallow sediment layer by using the differences between the arrival times of $\mathrm{P}-\mathrm{S}$ converted waves and direct $\mathrm{P}$-waves. A $\mathrm{Vp} / \mathrm{Vs}$ of 3 within the shallow sediment layer was assumed (Tonegawa T, Shiomi K, Yamamoto Y, Takahashi N, Citak SO, Pinar A, Kalafat D, Kaneda Y: Vp/Vs and shear wave anisotropy of marine sediments in the Sea of Marmara, submitted), and then the station correction values for $\mathrm{S}$-wave arrivals became $0.635 \mathrm{~s}$ (sites 1 and 7) and $0.762 \mathrm{~s}$ (site 6). Earthquake magnitudes were determined from the maximum amplitude of the vertical component (Watanabe 1971). Although this estimation has uncertainty of \pm 0.3 on average, the most of their value is less than 1.4. Since the obtained value of one KOERI-catalogued earthquake consists with the local magnitude determined by KOERI, we consider the magnitude of newly identified events in this study as reasonable, and these events were too small to detect by using only land seismic stations. The average errors

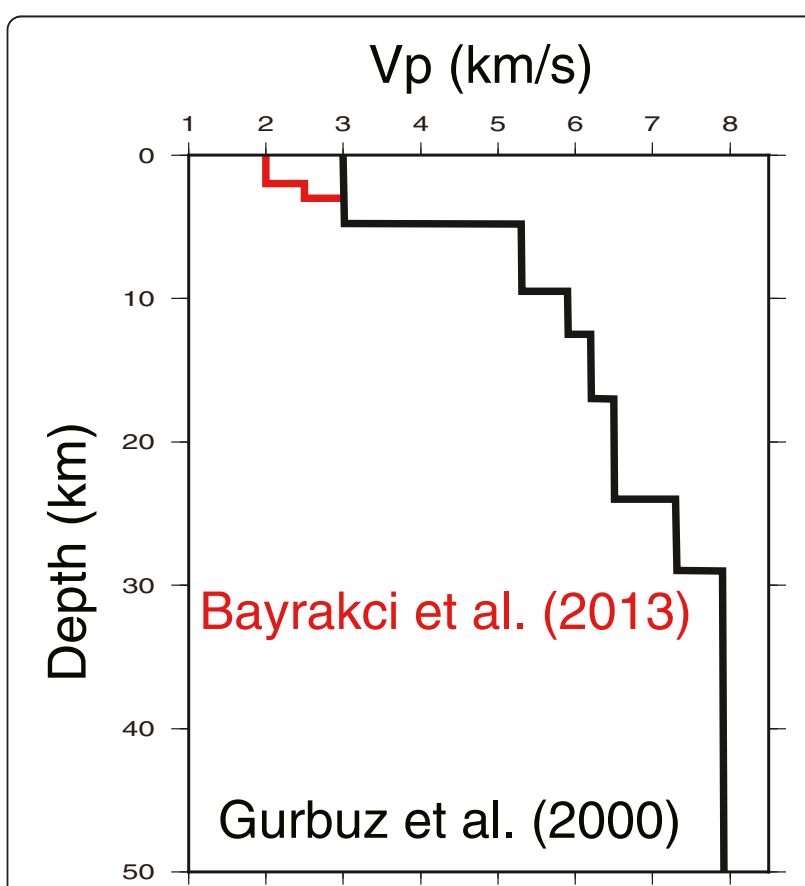

Fig. $31-D$ velocity model used in this study. Black line is the velocity model of Gurbuz et al. (2000) and red line shows our modification of that model based on the model of Bayrakci et al. (2013) 
of calculated hypocenters were about $0.75 \mathrm{~km}$ horizontally and $1.25 \mathrm{~km}$ vertically.

We also recalculated the hypocenters for each of the earthquakes in the KOERI earthquake catalogue during the time of our observations by combining the land data and our OBS data. We adopted the 1-D velocity model of Gurbuz et al. (2000) for the land stations. The velocity model we used for the OBS data was the same one we used for hypocenter determinations for the initial 6 days of OBS data (Fig. 3).

The KOERI earthquake catalogue records 28 earthquakes in the western Marmara Sea during the 3 months of our observations, 8 of which occurred within the OBS network. The average error of the hypocenters for these eight events was about $0.25 \mathrm{~km}$ horizontally and $0.40 \mathrm{~km}$ vertically.

\section{Results and discussion}

Seismicity and fault geometry

Hypocenters determined from data recorded by all three OBSs during the first 6 days of observation (Fig. 4) show that most of them lie close to or a little south of the seafloor trace of the MMF. In particular, we noted a cluster of events (cluster-A in Fig. 4; Table 1) along the MMF at depths of $13-20 \mathrm{~km}$.

The hypocenters of two cluster-A events (events 6 and 7 in Table 1) were close together and deeper than the others. To further investigate the relationships among the cluster-A events, we calculated correlation coefficients (CCs) of vertical (up-down; UD) and horizontal component waveforms in the $4-8 \mathrm{~Hz}$ frequency band for all pairs of cluster-A events. For the master waveforms for these correlations, we used an $8 \mathrm{~s}$ continuous record that started $0.5 \mathrm{~s}$ before the P-wave arrival. We then searched for the maximum CC for the UD component within $\pm 0.1 \mathrm{~s}$ of the $\mathrm{P}$-wave arrival of the slave event (Fig. 5a). We calculated CCs for the horizontal components at the times corresponding to the maximum CC for the UD components (Fig. 5b). The CCs obtained and the similarities of the waveforms of events 6 and 7 (Fig. 5c) suggest that these 2 events occurred close together and differ from the other 11 events in cluster-A. Furthermore, the S-P times for these 2 events at site 1 and 6 were $0.5 \mathrm{~s}$ longer than those of the other

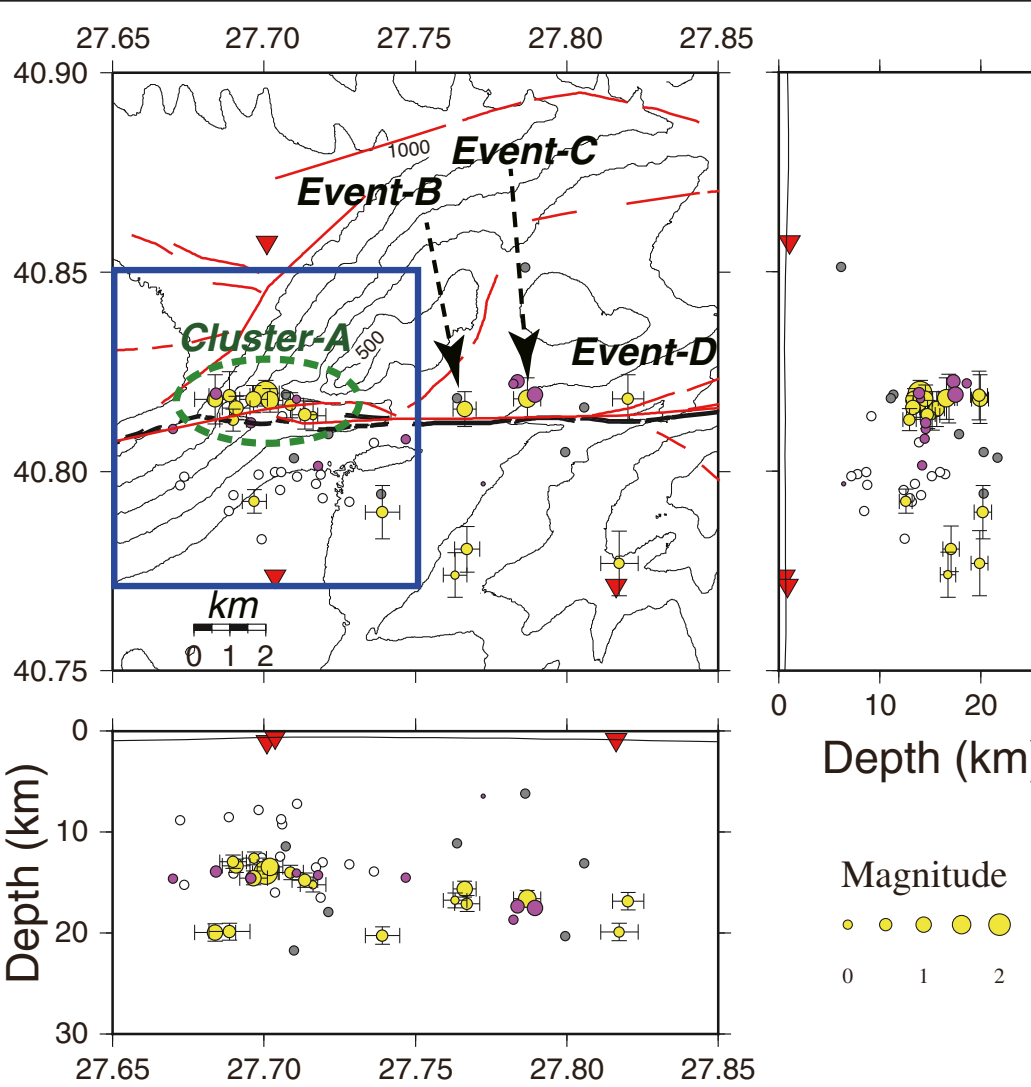

Fig. 4 Results of hypocenter determinations for first 6 days of observation. The events for which all six first arrivals were identified (P-and S-waves at three OBSs) are shown by yellow circles with error bars. Purple circles are events for which only five first arrivals were identified. Magnitudes were calculated by the method of Watanabe (1971). Red inverted triangles are OBS locations. Hypocenters of earthquakes recorded in the KOERI catalogue just before 1 week of OBS observation and between 20 March and 18 June 2014 are also shown as white and gray circles, respectively. Black fault lines indicate the fault model of Le Pichon et al. (2001) and red lines that of Armijo et al. (2005). Bathymetry (interval $100 \mathrm{~m}$ ) is also shown. Blue rectangle indicates analysis area for Fig. 9 
Table 1 Details of cluster-A events

\begin{tabular}{cccccccc}
\hline Event number & Date (year/month/day) & Time & Latitude $\left({ }^{\circ} \mathrm{N}\right)$ & Longitude $\left({ }^{\circ} \mathrm{E}\right)$ & Depth $(\mathrm{km})$ & Magnitude & Number of first arrivals \\
\hline 1 & $2014 / 3 / 20$ & $17: 15: 39$ & 40.820 & 27.701 & 14.0 & 2.4 & 6 \\
2 & $2014 / 3 / 20$ & $17: 18: 05$ & 40.818 & 27.702 & 13.4 & 1.3 & 6 \\
3 & $2014 / 3 / 20$ & $17: 19: 47$ & 40.818 & 27.711 & 14.0 & -0.1 & 5 \\
4 & $2014 / 3 / 20$ & $18: 26: 24$ & 40.812 & 27.696 & 14.6 & 0.2 & 5 \\
5 & $2014 / 3 / 21$ & $12: 01: 51$ & 40.820 & 27.684 & 13.9 & 0.4 & 5 \\
6 & $2014 / 3 / 21$ & $23: 30: 57$ & 40.818 & 27.684 & 19.9 & 1.1 & 6 \\
7 & $2014 / 3 / 22$ & $00: 25: 28$ & 40.819 & 27.689 & 19.8 & 0.6 & 6 \\
8 & $2014 / 3 / 22$ & $12: 26: 00$ & 40.817 & 27.709 & 14.0 & 0.4 & 6 \\
10 & $2014 / 3 / 22$ & $15: 11: 56$ & 40.814 & 27.716 & 15.2 & -0.2 & 6 \\
11 & $2014 / 3 / 23$ & $05: 31: 29$ & 40.818 & 27.697 & 14.5 & 1.0 & 6 \\
13 & $2014 / 3 / 23$ & $10: 51: 38$ & 40.816 & 27.691 & 13.3 & 6.8 & 6 \\
& $2014 / 3 / 23$ & $14: 40: 17$ & 40.813 & 27.690 & 12.9 & 6.4 & 6 \\
\end{tabular}

11 events (Fig. 5c, d). Thus, we consider that this depth variation of the cluster-A events is well constrained.

To investigate the effect of station corrections on hypocenter determinations for cluster-A events, we tested $\mathrm{Vp} /$ Vs of 2.5 and 3.5 for the shallow sediment layer (Fig. 6). These analyses indicated that both the longitude and depth of the hypocenters determined depend on the assumed $\mathrm{Vp} / \mathrm{Vs}$. Longitudes and depths determined using $\mathrm{Vp} / \mathrm{Vs}$ of 2.5 and 3.5 differed by about $0.02^{\circ}$ and $2 \mathrm{~km}$, respectively. However, the latitude of event hypocenters was not affected by the different $\mathrm{Vp} / \mathrm{Vs}$ tested, especially for clusterA events; thus, we inferred that the cluster-A events occurred beneath the seafloor trace of the MMF and that the dip of the MMF is approximately vertical.

We also examined the P-wave first motions of the UD components of cluster-A events recorded at the three OBSs. At site 6, first motions were clearly upward (compressional) for all cluster-A events; at site 7, no clusterA events showed upward, and some of them showed clear downward first motions; and at site 1, there were both upward and downward (dilatational) first motions. If it is assumed that site 1 is near the nodal plane, these observations are consistent with the generally accepted right-lateral strike-slip on the fault plane of the NAF.

Outside cluster-A, there are three other events near the MMF for which six P-and S-wave first arrivals were identified (events B, C, and D in Fig. 4). The polarities of the first arrivals of events $\mathrm{B}$ and $\mathrm{C}$ are also consistent with right-lateral fault motion, but those of event $D$ are upward at all OBSs and consistent with normal fault. On the basis of focal mechanism analysis, an earthquake generated by a normal fault movement close to the hypocenter of event D was reported (Nakano M, Citak S. Kalafat D: Focal mechanism determinations of earthquakes along the North Anatolian fault, beneath the Sea of Marmara and the Aegean Sea, submitted). We therefore suggest that event $\mathrm{D}$ occurred on an oblique sub-fault of the MMF that may be related to spreading in the central basin of the Marmara Sea. There have been many interpretations of the locations and mechanisms of sub-faults associated with the MMF (e.g., Armijo et al. 2002; Grall et al. 2013), and variations of focal mechanism solutions for the MMF (Pinar et al. 2003; Kalafat et al. 2009; Örgülü 2011) have been attributed to the existence of such sub-faults.

\section{Spatial distribution of earthquakes}

We recalculated the hypocenters of the eight earthquakes in the KOERI catalogue that were within the OBS network by using data from both land stations and our OBSs (Fig. 7). Because we used the 1-D velocity model of Gurbuz et al. (2000), we used only land seismic stations within their study area (Fig. 7b). Most of the recalculated epicenters lie within $2 \mathrm{~km}$ of the surface trace of the MMF (Fig. 7a), although some of them are 3-10 km west of those of the KOERI earthquake catalogue. On average, the recalculated focal depths are about $5 \mathrm{~km}$ deeper than those of the KOERI catalogue. The difference of the hypocenter for event 1 of cluster-A (Table 1) calculated using OBS data only (red star in Fig. 7) from that calculated using both land and OBS data (orange circle in Fig. 7) is about $1 \mathrm{~km}$. Therefore, we consider that the upper (shallow) limit of the seismogenic zone according to the recalculated focal depths is consistent within about $1 \mathrm{~km}$ with those obtained by using only the three OBSs for the initial 6 days of observation (Fig. 4). On the other hand, the lower (deep) limit of the seismogenic zone according to the recalculated focal depths seems to be inconsistent with those obtained by using only the three OBSs for the initial 6 days of observation (Fig. 4), because there are two 


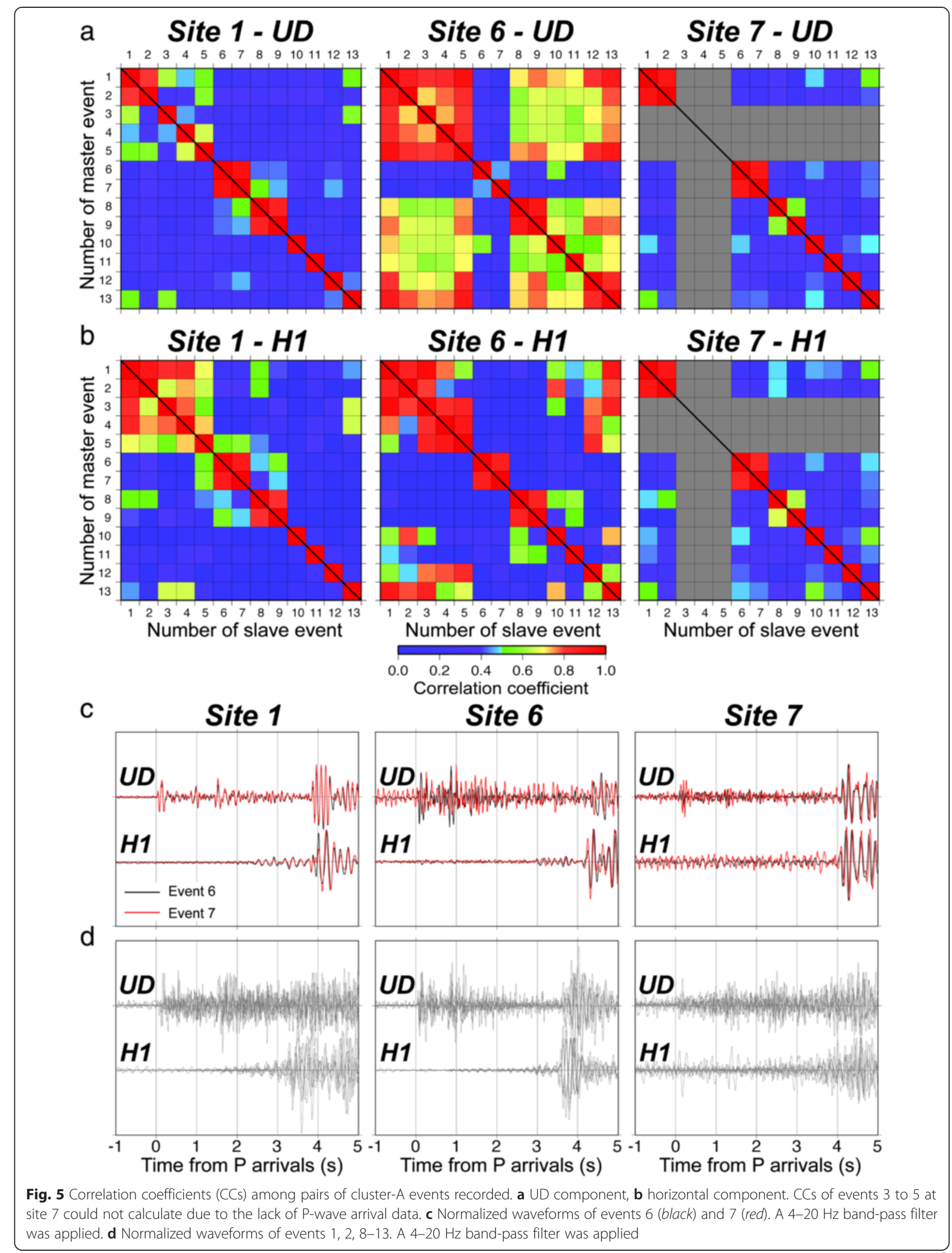




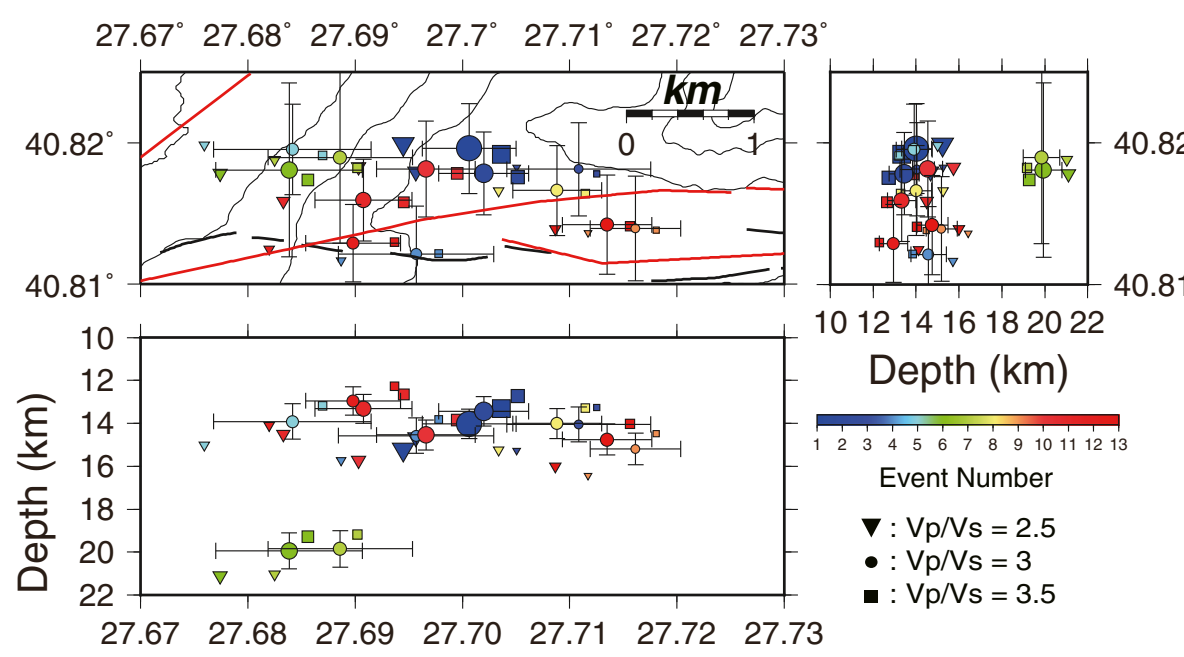

Fig. 6 Comparison of hypocenters determined with assumed VpNs of 2.5, 3.0, and 3.5. Event numbers (Table 1) are color-coded. Error bars shown were calculated for $\mathrm{Vp} / \mathrm{Ns}=3$. Other symbols are as in Fig. 4

earthquakes whose focal depth was deeper than $20 \mathrm{~km}$ (events $\mathrm{E}$ and $\mathrm{F}$ in Fig. 7a). Although, we could not argue about event $\mathrm{E}$ because it locates away from the OBS network, event F located within the same area of cluster-A, and its focal depth is about $25 \mathrm{~km}$. However, the P-wave first motion of event-F at site 6 was downward in contrast to that of all cluster-A events. If this earthquake did occur on the MMF with right-lateral strike slip, the actual location was likely farther west. Otherwise, it may not have occurred on the MMF. Although

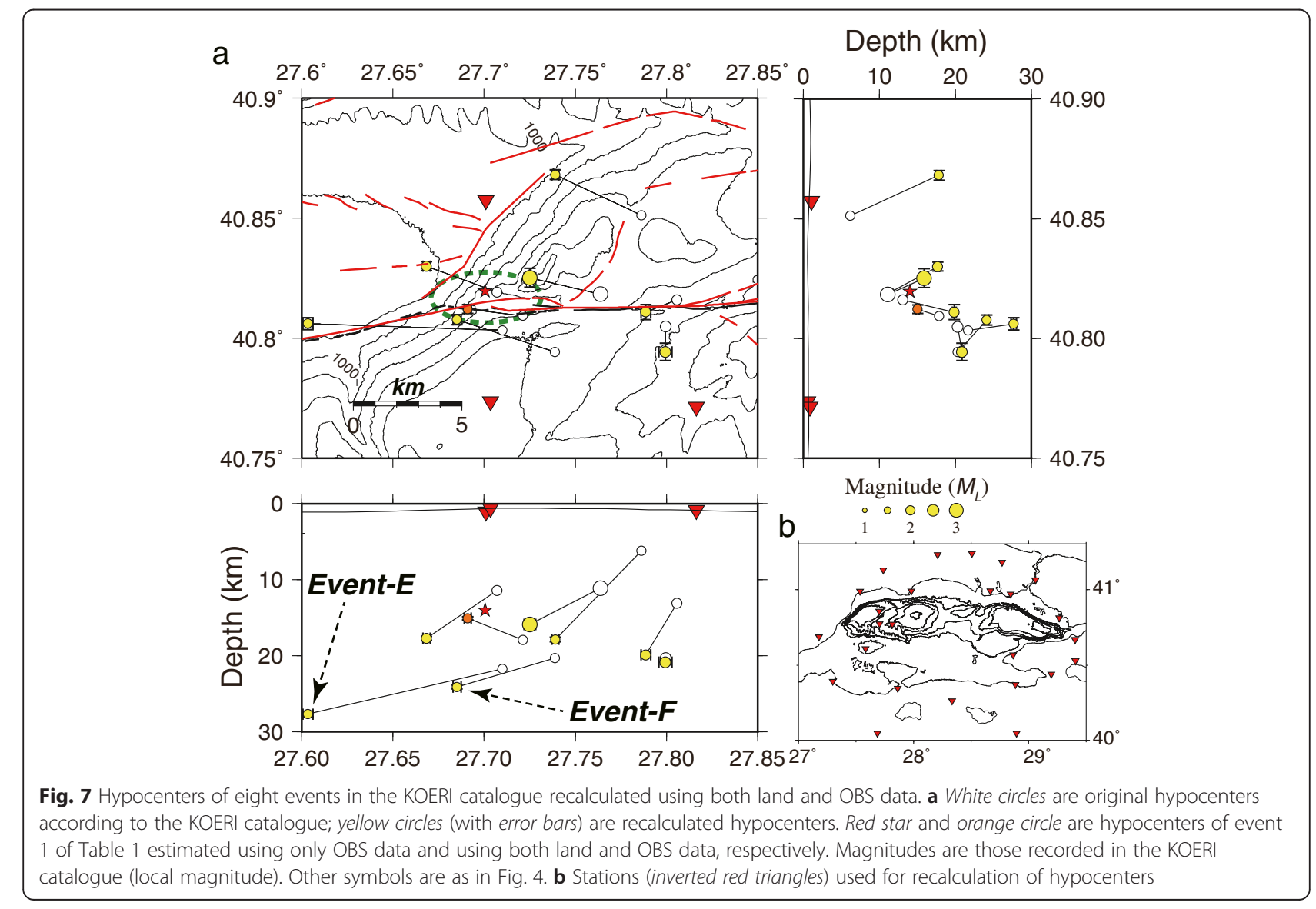


we have insufficient data to discriminate between these two possibilities, we assume that the seismogenic zone within the OBS network is at depths from 13 to $25 \mathrm{~km}$ at the most. The Conrad discontinuity in this region has been estimated to be at $18 \mathrm{~km}$ depth (Bécel et al. 2009), so our results suggest that the seismogenic zone in this region extends into the lower crust.

In a similar OBS-based study to ours, Sato et al. (2004) estimated the depth range of the seismogenic zone in our study area to be $8-20 \mathrm{~km}$, a range about $5 \mathrm{~km}$ shallower than ours. Because they did not use land seismic data, we recalculated the hypocenters of clusterA events recorded during our first 6 days of observation by using the same 1-D velocity model and method of station correction used by Sato et al. (2004). This recalculation produced focal depths about $1 \mathrm{~km}$ deeper than those of our original results (Fig. 4). Thus, we consider that the difference of the seismogenic zone we estimated from that estimated by Sato et al. (2004) likely reflects differences in the station distributions or observation periods, or both. Nonetheless, it appears that the maximum depth of the seismogenic zone is shallower than $25 \mathrm{~km}$. The depth of the Moho discontinuity in the study area has been estimated to be $26-28 \mathrm{~km}$ on the basis of seismic reflection data (Bécel et al. 2009) and from receiver function analysis (Buyukakpinar et al. 2014). We therefore concluded that the seismogenic zone in our study area is restricted to the crust.

\section{Temporal distribution of earthquakes}

To investigate the temporal distribution of seismic activity within cluster-A, we calculated CCs between the waveforms of cluster-A earthquakes and the 3-month continuous record of OBS data at sites 6 and 7. For this analysis, we used a record length of $8 \mathrm{~s}$ starting $0.5 \mathrm{~s}$ before the P-wave arrival of cluster- $\mathrm{A}$ earthquakes as a master data and applied a $4-8 \mathrm{~Hz}$ band-pass filter to the both master and $8 \mathrm{~s}$ length slave data from continuous

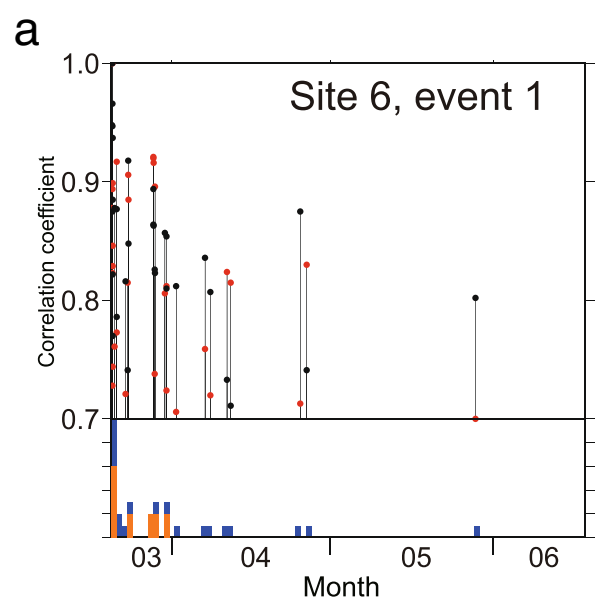

b

C

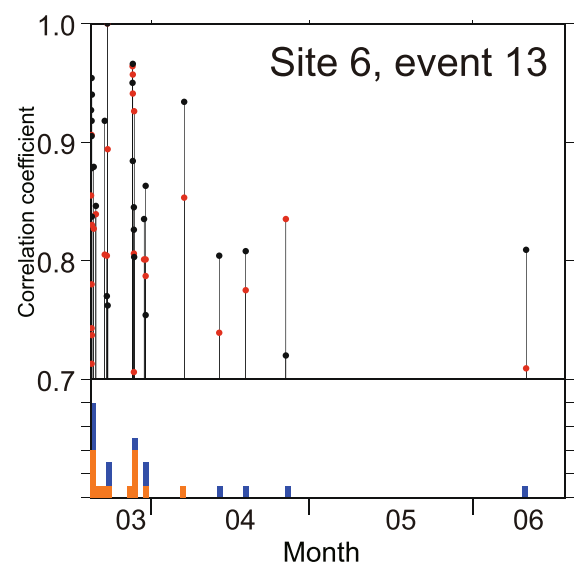

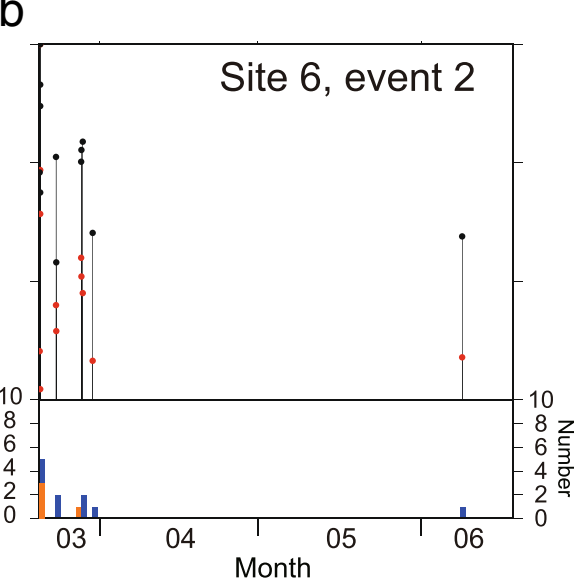

d

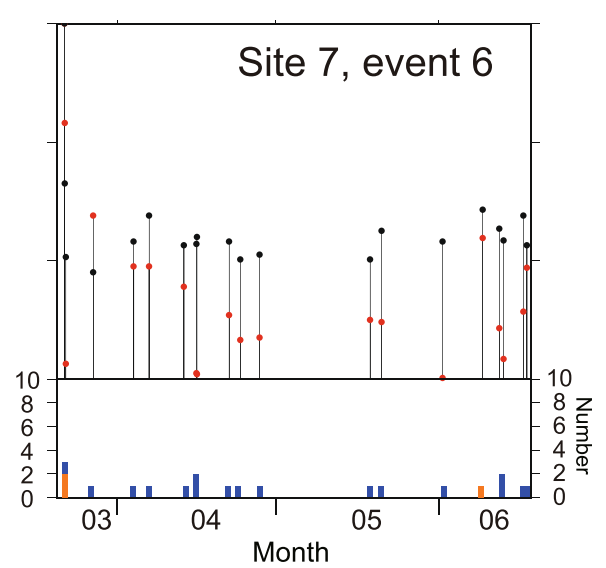

Fig. 8 Time series of correlations between cluster-A waveforms and the 3-month continuous record. Correlation coefficients (CCS) $>0.7$ are shown for both UD (red circles) and horizontal waveform components (black circles). a Event 1 waveforms recorded at site 6, b event 2 recorded at site 6, c event 13 recorded at site 6, and $\mathbf{d}$ event 6 recorded at site 7 (see Table 1 for descriptions of these events). Histograms of daily frequency of CCs greater than 0.7 (blue) and greater than 0.8 (orange) for both components are also shown 
records. Figure 8 shows the time series of CCs and daily frequency histograms for the few station-event pairs for which at least ten CCs greater than 0.7 were obtained for both UD and horizontal waveform components. Most of the high CCs were obtained for shallow events 1, 2, and 13 at site 6 in March (Fig. 8a-c). We consider the high-CC distribution at site 6 to be more reliable than that at site 7 because cluster-A hypocenters are close to site 6 , and interpret these data to indicate that shallow seismic activity in cluster-A had finished by the end of March. On the other hand, high CCs for event 6 (deep) were obtained at only site 7 , and they were distributed throughout the 3-month period of observation and most of their CCs of less than 0.8 (Fig. 8d). Thus, we could not draw any conclusions about temporal distribution of deep seismic activity because high CCs ( $>0.7$ ) were obtained for only one deep event at site 7 (event 6; Fig. 8d) and not obtained at site 6. However, there is a possibility that this is caused by the noisy UD component waveform at site 6 (Fig. 5c). When we used only horizontal component of events 6 and 7 at site 6 , the deep seismic activity also seems to finish by the end of March.
The KOERI earthquake catalogue records a swarm of earthquakes with hypocenters near cluster-A; most of these occurred between 13 and 18 March (Fig. 4). The last earthquake recorded in the KOERI earthquake catalogue during our period of OBS observations was event 1 (Table 1), which occurred on 20 March. We consider that the cluster-A activity we observed corresponds to the latter half of the swarm recorded in the KOERI earthquake catalogue and that the duration of that swarm was a few weeks.

To examine the long-term pattern of earthquake occurrences in the area of the above swarm, we considered the time series of earthquakes in the region of cluster-A from 2004 to 2014 according to the KOERI earthquake catalogue (Fig. 9) with considering the frequency (within 2-week intervals) of earthquakes. We included only those of magnitude $>2.5$, because there is no earthquakes whose magnitude is less than 2.5 in the KOERI earthquake catalogue in this region during the early 2000s. Figure 9 indicates the existence of repetitive swarms of earthquakes in the region of cluster-A with an average occurrence interval of 2-3 years. Such increasing seismic activity accompanied the episodic slow slip

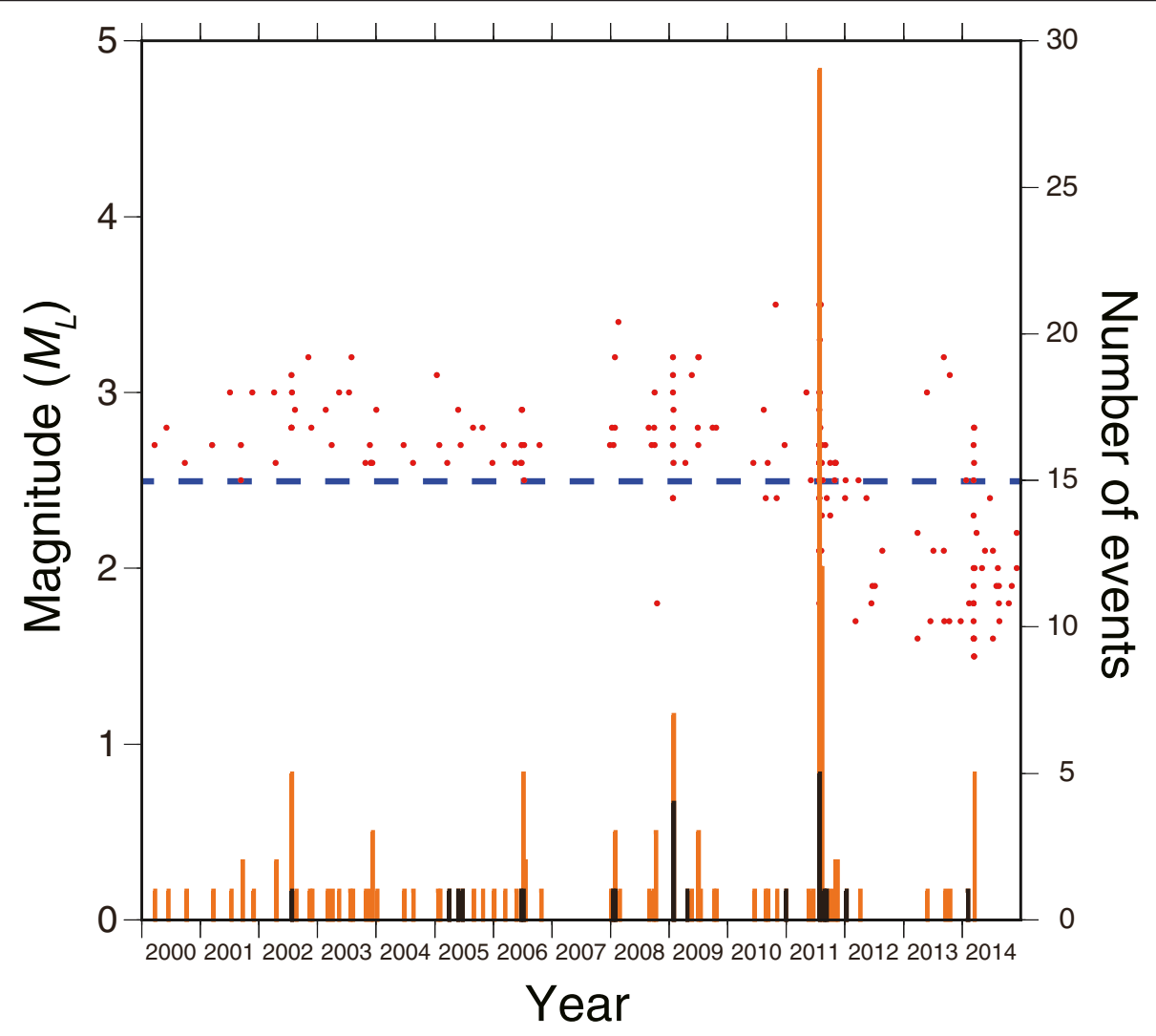

Fig. 9 Time series of seismic activity recorded in the KOERI catalogue for the period 2000-2014. Red circles indicate earthquake events. Histogram of event frequency in 2-week intervals includes only events of $M_{L} \geq 2.5$ (above blue dashed line) is also shown in lower panel (orange: for all events, black: for events whose depth $>15 \mathrm{~km}$ ). Area analyzed is shown by the blue rectangle in Fig. 4 
or transient slip has been observed in several regions in the world (Ozawa et al. 2003; Delahaye et al. 2009; Montgomery-Brown et al. 2009; Murray and Segall 2005). Although there is no report about geodetic observation at the same time of swarm activities in our study area, we suggest that this regular swarm activity has a key role in the release of accumulated strain along the MMF.

\section{Relationship of cluster-A to the large earthquake}

Bouchon et al. (2011) reported that the 1999 Izmit-Golcuk earthquake (immediately east of the Marmara Sea) was preceded by a succession of seismic bursts that originated from the eventual hypocenter of that earthquake, which was at the base of the brittle crust. This suggests the possibility that the seismic burst at the base of the brittle crust indicates the hypocenter of past and/or future large earthquakes. Although the duration of the bursts of seismicity that preceded the 1999 Izmit-Golcuk earthquake and the intervals between them (Bouchon et al. 2011) differ from those of the lower crustal seismic activity (events 6 and 7) within cluster-A, both sets of seismic activity had similar depths of occurrence. These similarities suggest the possibility that there was a large, previously unidentified earthquake under the Marmara Sea with its hypocenter in the region of events 6 and 7, the two deepest events in cluster-A. Cluster-A is close to the eastern end of the rupture areas of $1912\left(M_{s}=7.4\right.$; Fig. 1b) and $1766\left(M_{w} \sim 7.6\right)$ earthquakes (e.g., Altınok et al. 2003; Parsons 2004). Although the hypocenter of 1912 earthquake was far from cluster-A (e.g., Ambraseys and Jackson 2000), we could not reject the possibility that cluster-A insist the hypocenter location of 1766 earthquake because its location is unclear. In addition, the most of seismic swarms detected in this study seems to contain one or more earthquakes whose focal depth is deeper than $15 \mathrm{~km}$ (Fig. 9). Thus, monitoring of seismic activity at the base of brittle crust in the area of this repetitive swarm might be useful for understanding the potential for future earthquakes in this region.

\section{Conclusions}

Our analysis of data recorded by three OBSs we deployed for 3 months in the western Marmara Sea showed that most of the microearthquakes we identified occurred along the MMF, although one of them could not be explained by the characteristic right-lateral strikeslip motion of the MMF. Our data indicate that the fault plane of the MMF is almost vertical. We identified a seismogenic zone that extends from 13 to $25 \mathrm{~km}$ depth through the upper and lower crust beneath the western Marmara Sea, although these results are still preliminary and should be confirm by additional observation. The cluster of seismic activity we identified under the
Western High of the Marmara Sea appears to be representative of repetitive seismic activity with an occurrence interval of 2-3 years that periodically releases some of the strain that has accumulated along the MMF.

We have shown that OBS observations can provide useful information about seismicity along the MMF. However, the three OBSs we used in this study did not provide sufficient coverage to shed light on seismicity along the entire length of the MMF beneath the Marmara Sea. We have already started the next 1-year observation by using 15 OBSs with extend both the duration of observations and the size of the study area, which will allow us to assess fault geometry and stick-slip behavior beneath the whole Marmara Sea.

\section{Abbreviations}

NAF: North Anatolian fault; KOERI: Kandilli Observatory and Earthquake Research Institute; OBS: Ocean bottom seismograph; MMF: Main Marmara fault; CC: Correlation coefficient; MarDIM: Marmara Disaster Mitigation; UD: Up-down.

\section{Competing interests}

The authors declare that they have no competing interests.

\section{Authors' contributions}

YY processed and interpreted the seismic data and wrote the manuscript. NT, SC, DK, AP, and CG planned the cruise, and DK was chief scientist onboard. NT, DK, AP, and CG participated in the interpretation of the seismicity. YK coordinated all aspects of the project. All authors approved the manuscript.

\section{Acknowledgements}

We thank the captain and crew of DSV Alcatras. We also thank Satoshi Shimizu, Takuya Maekawa, Ozkan Cok, Murat Suvarikli, Ibrahim Zafer Ogutcu, and Suleyman Tunc for OBS preparation and onboard operation. All figures were created using Generic Mapping Tools (Wessel and Smith, 1991). OBS observations were conducted under the Marmara Disaster Mitigation (MarDIM) project, formally known as the "Earthquake and Tsunami Disaster Mitigation in the Marmara Region and Disaster Education in Turkey" project. MarDIM receives financial support from the Japan International Cooperation Agency (JICA), Japan Science and Technology Agency (JST), and the Ministry of Development in Turkey. The comments and suggestions from two anonymous reviewers and Editor T. Hori greatly improved this manuscript.

\section{Author details}

'Japan Agency for Marine-Earth Science and Technology, Yokohama, Japan. ${ }^{2}$ Kandilli Observatory and Earthquake Research Institute, Boğaziçi University, Istanbul, Turkey. ${ }^{3}$ Disaster Mitigation Research Center, Nagoya University, Nagoya, Japan.

Received: 9 June 2015 Accepted: 3 September 2015

Published online: 15 September 2015

\section{References}

Altınok Y, Alpar B, Yaltırak C (2003) Şarköy-Mürefte 1912 Earthquake's Tsunami, extension of the associated faulting in the Marmara Sea, Turkey. J Seismo 7:329-346

Ambraseys NN, Jackson JA (2000) Seismicity of the Sea of Marmara (Turkey) since 1500. Geophys J Int 141(3):F1-F6. doi:10.1046/j.1365-246x.2000.00137.x

Armijo R, Meyer B, Navarro S, King G, Barka A (2002) Asymmetric slip partitioning in the Sea of Marmara pull-apart: a clue to propagation processes of the North Anatolian Fault? Terra Nova 14:80-86

Armijo R, Pondrad N, Meyer B, Uçarkus G, De Lépinary BM, Malavielle J, Dominguez S, Gustcher M-A, Schmidt S, Beck C, Cagatay N, Cakir Z, Imren C, Eris K, Natalin B, Ozalabey S, Tolun L, Lefévre I, Seeber L, Gasperini L, Rangin C, Emre O, Sarikavak K (2005) Submarine fault scarps in the Sea of Marmara 
pull-apart (North Anatolian Fault): Implications for seismic hazard in Istanbul. Geochem Geophys Geosys 6(6):Q06909. doi:10.1029/2004GC000896

Bayrakci G, Laigle M, Bécel A, Hirn A, Taymaz T, Yolsal-Çevikbilen S, SEISMARMARA team (2013) 3-D sediment-basement tomography of the Northern Marmara trough by a dense OBS network at the nodes of a grid of controlled source profiles along the North Anatolian fault. Geophys J Int 194:1335-1357. doi:10.1093/gji/ggt211

Bécel A, Laigle M, de Voogd B, Hrin A, Taymaz T, Galvé A, Shimamura H, Murai $Y$, Lépine J, Spain M, Özalaybey S (2009) Moho, crustal architecture and deep deformation under the North Marmara Trough, from the SEISMARMARA Leg 1 offshore-onshore reflection-refraction survey. Tectonophys 467:1-21. doi:10.1016/j.tecto.2008.10.022

Bird P (2003) An updated digital model of plate boundaries. Geochem Geophys Geosys 4(3):1027. doi:10.1029/2001GC000252

Bouchon M, Karabulut H, Aktar M, Ozalaybey S, Schmittbuhl J, Bouin MP (2011) Extended nucleation of the 1999 Mw 7.6 Izmit earthquake. Science 331:877. doi:10.1126/science.1197341

Buyukakpinar P, Gurbuz C, Zor E (2014) Moho depth and crustal Vp/Ns variation in the Marmara region obtained by receiver functions. Paper presented at the 2014 Fall Meeting. AGU, San Francisco, Calif

Delahaye EJ, Townend J, Reyners ME, Rogers G (2009) Microseismicity but no tremor accompanying slow slip in the Hikurangi subduction zone, New Zealand. Earth Planets Sci Lett 277(1-2):21-28. doi:10.1016/j.epsl.2008.09.038

Dziewonski AM, Chou T-A, Woodhouse JH (1981) Determination of earthquake source parameters from waveform data for studies of global and regional seismicity. J Geophys Res 86:2825-2852. doi:10.1029/JB086iB04p02825

Ekström G, Nettles M, Dziewonski AM (2012) The global CMT project 2004-2010: Centroid-moment tensors for 13,017 earthquakes. Phys Earth Planet Inter 200-201:1-9. doi:10.1016/j.pepi.2012.04.002

Grall C, Henry P, Thomas Y, Westbrook GK, Çağatay MN, Marsset B, Saritas H, Çifçi G, Géli L (2013) Slip rate estimation along the western segment of the Main Marmara Fault over the last 405-490 ka by correlation mass transfer deposits. Tectonics 32:1587-1601. doi:10.1002/2012TC003255

Gurbuz C, Aktar M, Eyidogan H, Cisternas A, Haessler H, Barka A, Ergin M, Türkelli N, Polat O, Üçer SB, Kuleli S, Baris S, Kaypak B, Bekler T, Zor E, Bicmen F, Yoruk A (2000) The seismotectonics of the Marmara region (Turkey): results from a micro-seismic experiment. Tectonophysics 316:1-17

Hirata N, Matsu'ura M (1987) Maximum-likelihood estimation of hypocenter with origin time eliminated using nonlinear inversion technique. Phys Earth Planet Inter 47:50-61

Kalafat D, Kekovalı K, Güneş Y, Yılmazer M, Kara M, Deniz P, Berberoğlu M (2009) Türkiye ve Çevresi Faylanma-Kaynak Parametreleri (MT) Kataloğu (1938-2008): A Cataloque of Source Parameters of Moderate and Strong Earthquakes for Turkey and its Surrounding Area (1938-2008). Boğaziçi University Publication No=1026, Bebek-Istanbul, p 43

Kissling E, Ellsworth WL, Eberhart-Phillips D, Kradolfer U (1994) Initial reference models in local earthquake tomography. J Geophys Res 99 B10:19635-19646

Le Pichon X, Şengör AMC, Demirbağ E, Rangin C, Imren C, Armijo R, Görür N, Çağatay N, de Lepinay BM, Meyer B, Saatçılar R, Tok B (2001) The main Marmara fault. Earth Planet Sci Lett 192:595-616

Montgomery-Brown EK, Segall P, Mikilus A (2009) Kilauea slow slip events: Identification, source inversions, and relation to seismicity. J Geophys Res 114(B6). doi:10.1029/2008JB006074.

Murray JR, Segall P (2005) Spatiotemporal evolution of a transient slip event on the San Andreas fault near Parkfield, California. J Geophys Res 110, B09407. doi:10.1029/2005JB003651

Örgülü G (2011) Seismicity and source parameters for small-scale earthquakes along the splays of the North Anatolian Fault (NAF) in the Marmara Sea. Geophys J Int 184:385-404. doi:10.1111/j.1365-246X.2010.04844.x

Ozawa S, Miyazaki S, Hatanaka Y, Imakiire T, Kaidzu M, Murakami M (2003) Characteristic silent earthquakes in the eastern part of the Boso peninsula, Central Japan. Geophy Res Lett 30(6). doi:10.1029/2002GL016665.

Parsons T (2004) Recalculated probability of $M \geq 7$ earthquakes beneath the Sea of Marmara, Turkey. J Geophys Res 109, B05304. doi:10.1029/2003JB002667

Pinar N (1943) Marmara Denizi Havzasinin Sismik Jeoloji ve Meteorolojisi, PhD Thesis. Institut de Géologie, Institut de Physique Générale de l'Université d'lstanbul, Kenan Matbaasi, Istanbul, p 64

Pinar A, Kuge K, Honkura Y (2003) Moment tensor inversion of recent small to moderate sized earthquakes: implications for seismic hazard and active tectonics beneath the Sea of Marmara. Geophys J Int 153:133-145
Reilinger R, McClusky S, Vernant P, Lawrence S, Ergintav S, Cakmak R, Ozener H, Kadirov F, Guliev I, Stepanyan R, Nadariya M, Hahubia G, Mahmoud S, Sakr K, ArRajehi A, Paradissis D, Al-Aydrus A, Prilepin M, Guseva T, Evren E, Dmitrotsa A, Filikov SV, Gomez F, Al-Ghazzi R, Karam G (2006) GPS constraints on continental deformation in the Africa-Arabia-Eurasia continental collision zone and implications for the dynamics of plate interactions. J Geophys Res 111:B05411. doi:10.1029/2005JB004051

Sato T, Kasahara J, Taymaz T, Ito M, Kamimura A, Hayakawa T, Tan O (2004) A study of microearthquake seismicity and focal mechanisms within the Sea of Marmara (NW Turkey) using ocean bottom seismometers (OBSs). Tectonophys 391:303-314. doi:10.1016/j.tecto.2004.07.018

Takahashi N, Shimizu S, Maekawa T, Kalafat D, Pinar A, Citak S, Kaneda Y (2015) OBS development for long term observation in the Marmara Sea, NW Turkey. Paper presented at 2015 Annual Meeting. EGU, Vienna

Watanabe H (1971) Determination of earthquake magnitude at regional distance in and near Japan. Zisin2 24:189-200, in Japanese with English abstract

Wessel P, Smith WHF (1991) Free software helps map and display data. Eos Trans AGU 72:441

\section{Submit your manuscript to a SpringerOpen ${ }^{\circ}$ journal and benefit from:}

- Convenient online submission

Rigorous peer review

- Immediate publication on acceptance

- Open access: articles freely available online

- High visibility within the field

- Retaining the copyright to your article

Submit your next manuscript at $>$ springeropen.com 